\title{
Internal fixation and comparisons of different fixation methods for treating distal radial fractures in adults (Protocol)
}

Handoll HHG, Watts AC
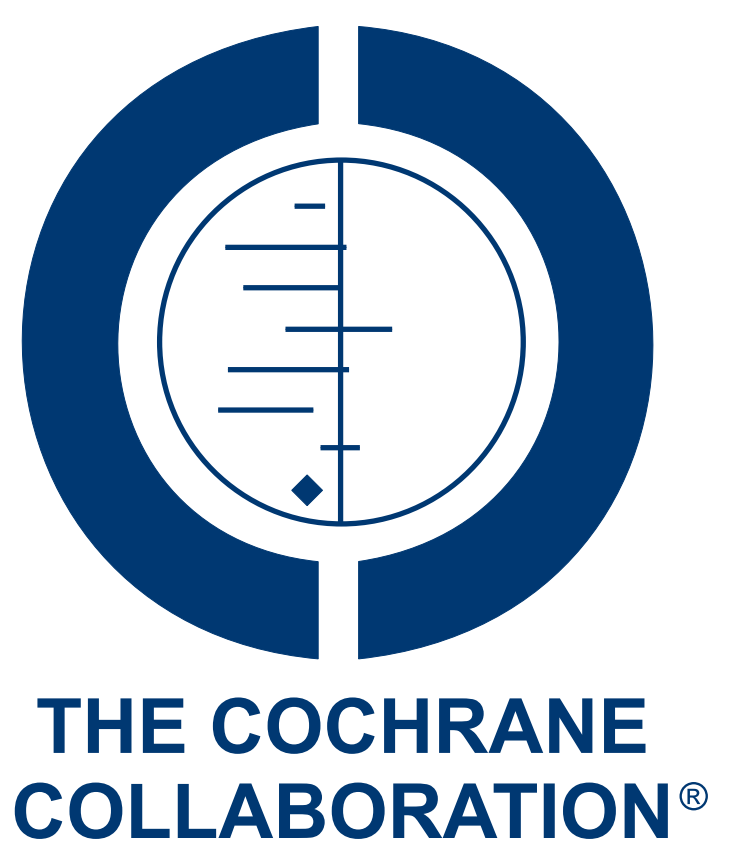

This is a reprint of a Cochrane protocol, prepared and maintained by The Cochrane Collaboration and published in The Cochrane Library 2008, Issue 4

http://www.thecochranelibrary.com

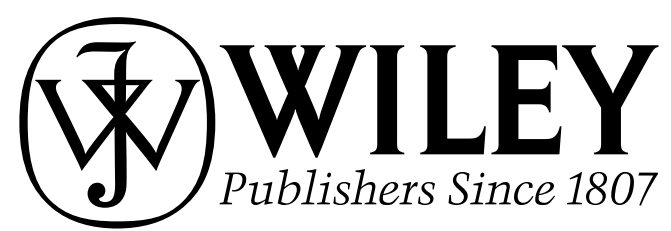

Internal fixation and comparisons of different fixation methods for treating distal radial fractures in adults (Protocol)

Copyright (@) 2008 The Cochrane Collaboration. Published by John Wiley \& Sons, Ltd. 
TABLE OF CONTENTS

HEADER . . . . . . . . . . . . . . . . . . . . . . . . . . . . . . . . . . . . . . . . 1

ABSTRACT . . . . . . . . . . . . . . . . . . . . . . . . . . . . . . . . . . . . . . . . . . . . . . . .

BACKGROUND . . . . . . . . . . . . . . . . . . . . . . . . . . . . . . . . . . . . 2

OBJECTIVES . . . . . . . . . . . . . . . . . . . . . . . . . . . . . . . . . . . . . 44

METHODS . . . . . . . . . . . . . . . . . . . . . . . . . . . . . . . . . . . . 5

ACKNOWLEDGEMENTS . . . . . . . . . . . . . . . . . . . . . . . . . . . . . . . . . . . . . . 11

REFERENCES . . . . . . . . . . . . . . . . . . . . . . . . . . . . . . . . . . . . . 11

APPENDICES . . . . . . . . . . . . . . . . . . . . . . . . . . . . . . . . . . . . . 12

WHAT'S NEW . . . . . . . . . . . . . . . . . . . . . . . . . . . . . . . . . . . . . 14

HISTORY . . . . . . . . . . . . . . . . . . . . . . . . . . . . . . . . . . . . . . . 14

DECLARATIONS OF INTEREST . . . . . . . . . . . . . . . . . . . . . . . . . . . . . . . . . . . . . . . .

SOURCES OF SUPPORT . . . . . . . . . . . . . . . . . . . . . . . . . . . . . . . . . 14

Internal fixation and comparisons of different fixation methods for treating distal radial fractures in adults (Protocol)

Copyright ( 2008 The Cochrane Collaboration. Published by John Wiley \& Sons, Ltd. 


\title{
[Intervention Protocol] \\ Internal fixation and comparisons of different fixation methods for treating distal radial fractures in adults
}

\author{
Helen HG Handoll ${ }^{1}$, Adam C Watts ${ }^{2}$ \\ ${ }^{1}$ Centre for Rehabilitation Sciences (CRS), Research Institute for Health Sciences and Social Care, University of Teesside, Middlesbor- \\ ough, UK. ${ }^{2}$ Department of Orthopaedic Surgery, Edinburgh Royal Infirmary, Edinburgh, UK \\ Contact address: Helen HG Handoll, Centre for Rehabilitation Sciences (CRS), Research Institute for Health Sciences and Social \\ Care, University of Teesside, School of Health and Social Care, Middlesborough, Tees Valley, TS1 3BA, UK. h.handoll@tees.ac.uk. \\ H.Handoll@ed.ac.uk.
}

Editorial group: Cochrane Bone, Joint and Muscle Trauma Group.

Publication status and date: Edited (no change to conclusions), published in Issue 4, 2008.

Citation: Handoll HHG, Watts AC. Internal fixation and comparisons of different fixation methods for treating distal radial fractures in adults. Cochrane Database of Systematic Reviews 2008, Issue 1. Art. No.: CD006951. DOI: 10.1002/14651858.CD006951.

Copyright (C) 2008 The Cochrane Collaboration. Published by John Wiley \& Sons, Ltd.

\section{A B S T R A C T}

This is the protocol for a review and there is no abstract. The objectives are as follows:

To evaluate the effectiveness of internal fixation for fractures of the distal radius in skeletally mature people. Additionally, to evaluate the relative effectiveness of different surgical methods of treating these fractures.

More specifically, we will compare the effectiveness of:

- internal fixation versus conservative treatment;

- different methods of internal fixation, including different techniques associated with inserting implants, different implants, and different types and durations of immobilisation after internal fixation;

- different fixation methods (percutaneous pinning, external fixation, internal fixation); and different combinations of surgical methods;

- different techniques (e.g. use of arthroscopy) and approaches (e.g. surgical repair of the triangular fibrocartilagenous complex (fibrous tissue which binds together the distal ends of the radius and ulnar)) not already covered.

We will consider these outcomes primarily in terms of patient-assessed functional outcome and satisfaction, and other measures of function and impairment, pain and discomfort, the incidence of complications, anatomical deformity and use of resources.

If data allow it, we intend to study the outcomes in different age groups and for different types of fractures, especially whether they are extra-articular or intra-articular. 


\section{B A C K G R O U N D}

Note: This is one of five reviews that will cover all surgical interventions for treating distal radial fractures in adults. Each review will provide updated evidence for one of the several surgical categories that are presented together in the currently available review (Handoll 2003a). Following publication of the five reviews, Handoll 2003a will be converted to an 'umbrella' review summarising the evidence for surgical treatment for these fractures.

\section{Description of the condition: distal radial fracture in adults}

Fractures of the distal radius, often referred to as "wrist fractures", are common in both children and adults. They are usually defined as occurring in the distal radius within three centimetres of the radiocarpal joint, where the lower end of the radius interfaces with two (the lunate and the scaphoid) of the eight bones forming the carpus (the wrist). The majority are closed injuries, the overlying skin remaining intact.

Distal radial fracture are one of the most common fractures in adults, occurring predominantly in white and older populations in the developed world (Sahlin 1990; Singer 1998; Van Staa 2001). In women, the incidence of these fractures increases with age, more rapidly from the age of 40 years (McQueen 2003). Before this age, the incidence is higher in men (Singer 1998). A recent multicentre study in the United Kingdom of patients aged 35 years and above with distal radius fracture reported an annual incidence of 9/10,000 in men and 37/10,000 in women (O'Neill 2001).

Young adults usually sustain this injury as a result of high-energy trauma, such as a traffic accident. In older adults, especially females, the fracture more often results from low-energy or moderate trauma, such as falling from standing height. This reflects the greater fragility of the bone, resulting from osteoporosis. It has been estimated that, at 50 years of age, a white woman in the USA or Northern Europe has a $15 \%$ lifetime risk of a distal radius fracture whereas a man has a lifetime risk of just over two per cent (Cummings 1985). More recent estimates (Van Staa 2001) of lifetime risk of radius or ulna fracture at 50 years of age are similar: $16.6 \%$ for women versus $2.9 \%$ for men.

Distal radial fractures are usually treated on an outpatient basis. It is estimated that around $20 \%$ of patients (mainly older people) require hospital admission (Cummings 1985; O’Neill 2001). This figure includes all people receiving surgery.

\section{Classification}

Surgeons have classified fractures by anatomical configuration and fracture pattern, to aid communication, research and guide management. Simple classifications were based on clinical appearance and often named after those who described them. In the distal radius, the term "Colles' fracture" is still used for a fracture in which there is an obvious and typical clinical deformity (commonly referred to as a 'dinner fork deformity') - reflecting dorsal displacement, dorsal angulation, dorsal comminution (fragmentation), and radial shortening. The introduction of X-rays and other imaging methods made it clear that the characteristic deformity may be associated with a range of different fracture patterns, which may be important determinants of outcome, and therefore the way in which treatment is conducted. For example, the fracture through the distal radius may be extra-articular (leaving the articular surface of the radius intact) or intra-articular (the articular surface is disrupted, sometimes in a complex manner). Numerous classifications have been devised to define and group different fracture patterns (Chitnavis 1999). Brief descriptions of six commonly cited classification systems are presented in Table 1 (Cooney 1993; Fernandez 1993; Frykman 1967; Melone 1993; Muller 1991; Older 1965).

Table 1. Commonly used classification systems

\begin{tabular}{|c|c|c|}
\hline Name (reference ID) & Brief outline & Comment \\
\hline $\begin{array}{l}\text { AO (Arbeitsgemeinschaft fur Osteosynthe- } \\
\text { sefragen)(Muller 1991) }\end{array}$ & $\begin{array}{l}\text { This system is organised in order of increas- } \\
\text { ing fracture severity. It divides the fractures } \\
\text { into three major groups: group A (extra-ar- } \\
\text { ticular), group B (simple/partial intra-artic- } \\
\text { ular), and group C (complex/complete in- } \\
\text { tra-articular). These three groups are then } \\
\text { subdivided, yielding } 27 \text { different fracture } \\
\text { types. }\end{array}$ & $\begin{array}{l}\text { There is no assessment of the extent of frac- } \\
\text { ture displacement. }\end{array}$ \\
\hline $\begin{array}{l}\text { Fernandez } \\
\text { (Fernandez 1993) }\end{array}$ & $\begin{array}{l}\text { This system is based on the mechanisms of } \\
\text { injury. There are five main groups: type I } \\
\text { (bending fractures); type II (shearing frac- } \\
\text { tures); type III (compression fractures, with }\end{array}$ & $\begin{array}{l}\text { The injury mechanism is not always appar- } \\
\text { ent. There is no consideration of the extent } \\
\text { of displacement. }\end{array}$ \\
\hline
\end{tabular}


Table 1. Commonly used classification systems (Continued)

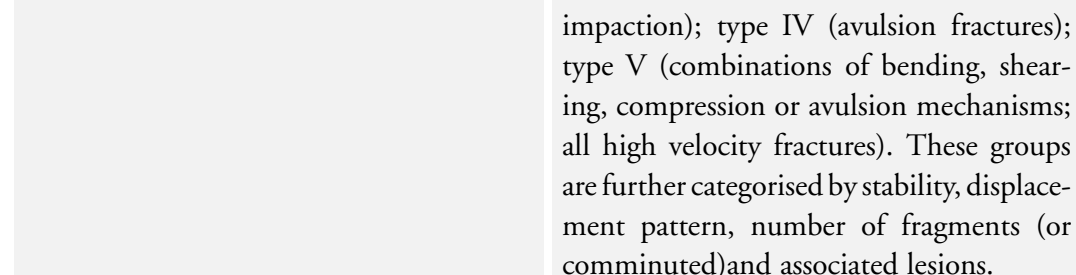

Frykman

(Frykman 1967)
This system distinguishes between extraarticular fractures and intra-articular fractures of the radiocarpal and radio-ulnar joints, and the presence or absence of an associated distal ulnar (ulnar styloid) fracture. There are 8 types labelled I to VIII (1 to 8 ): the higher the number, the greater complexity of the fracture.
Melone

(Melone 1993)
This system identifies 5 fracture types, This is for intra-articular fractures only. based on 4 major fracture components: the radial shaft, the radial styloid, and the dorsal-medial and volar-medial fragments.
Older

(Older 1965)
This system divides fractures into 4 types, There is no consideration of radio-ulnar labelled I to VI (1 to 4 ) of increasing sever- joint involvement.

ity. The types are defined according to extent of displacement (angulation and radial shortening)and comminution.
'Universal Classification' (Cooney 1993)
This system divides fractures into 4 main types, labelled I to VI (1 to 4), distinguishing between extra-articular and intra-articular fractures and displaced and non-displaced fractures. Displaced fracture types II and IV are further subdivided based on reducibility (whether the fracture can be reduced; that is whether the bone fragments can be put back in place) and stability (whether, once reduced, the fragments will remain so).
There is no assessment of the extent or direction of fracture displacement, or of comminution.

This does not distinguish between the ra-
diocarpal and radio-ulnar joints. Addition-
ally, there is a 'trial by treatment'.
diocarpal and radio-ulnar joints. Additionally, there is a 'trial by treatment'.

involving surgery aimed at more accurate reduction and more reliable stabilisation. Generally, four main strategies are described in the literature (Fernandez 1996). These are percutaneous pinning (reviewed: Handoll 2007a), external fixation (reviewed: Handoll 2007b; review protocol: Handoll 2007c), bone grafts or substitutes (review protocol: Handoll 2007d) and internal fixation. These may be used by themselves or in various combinations. Percutaneous pinning involves the percutaneous (through the skin) insertion of pins, which may be threaded, and wires. In external fixation, which

In the last century, most distal radius fractures in adults were treated non-operatively (conservatively), by reduction (the alignment of the bony fragments) of the fracture when displaced, and stabilisation in a plaster cast or other external brace. The results of such treatment, particularly in older people with bones weakened by osteoporosis, are not consistently satisfactory (Handoll 2003b). This has resulted in attempts to develop other strategies 
is also a closed, minimally invasive method, metal pins or screws are driven into bone, generally via small incisions of the skin and after drilling, on either side of the fracture. These pins are then fixed externally with a plaster cast or an external fixator frame. For both methods, the reduction of the fracture is generally closed (see Handoll 2003c); although pins - such as Kirschner wires - may be used to manipulate the fracture fragments (Trumble 1998). Internal fixation, which is usually proceeded by open reduction, involves open surgery where the fractured bone is exposed to direct view. Given the invasive and technically demanding nature of open surgery, with the increased risks of infection and soft-tissue damage, internal fixation is usually reserved for more severe injuries. It is, however, an increasingly used method of surgery and an area of intense current research activity, such as the development of new implant designs (Martineau 2007; Simic 2003).

Numerous techniques and devices are and have been used for internal fixation. Intra-operative choices include: the extent of exposure; the method of reduction and visualisation of the fractured bone and adjacent structures, including via arthroscopy; the direction of approach for plating (dorsal versus volar); the type of implant (generally screws or various plates), and underlying approach or "mindset" (Martineau 2007), such as fragment specific fixation. Although basic choices in methods of internal fixation can be defined, there is likely to be variation arising from patient and surgeon characteristics in these sorts of interventions; in part reflecting the direct visualisation of the fracture pattern at surgery. Post-operative decisions include the use and duration of immobilisation, and the techniques for removal (often only where symptomatic) of implants.

\section{Complications}

Complications from this injury are diverse and frequent (McKay 2001). Some are associated with the injury itself: as well as concomitant injuries to soft tissues, fracture displacement can further compromise blood vessels, tendons and nerves, with median nerve dysfunction being the most common complication (Belsole 1993). The etiology of complex regional pain syndrome type 1 (CRPS-1), also termed reflex sympathetic dystrophy, algodystrophy, Sudeck's atrophy and shoulder-hand syndrome (Fernandez 1996), is often unclear. CRPS-1 is a major complication (Atkins 2003) requiring many months of physiotherapy to alleviate symptoms (pain and tenderness, impairment of joint mobility, swelling, dystrophy (muscle wasting), vasomotor instability (poor control of blood vessel dilation)) in serious cases. Late complications include adaptive carpal instability (dynamic instability resulting from malalignment of distal radius and carpal bones within the wrist that is associated with pain, decreased grip strength and clicking) and posttraumatic arthritis which can occur several months or years after injury (Knirk 1986; Taleisnik 1984).

Complications can also result from treatment and include residual finger stiffness, which may be due to faulty application of plaster casts (Gartland 1951), and infection and tissue-damage from surgery. Damage to tendons, either irritation (tenosynovitis) or rupture is a well known complication of plating (Arora 2007; Margaliot 2005).

\section{Why it is important to do this review?}

Internal fixation is an increasingly used method of surgery for treating unstable distal radial fractures. Much of the current research effort and interest, including in industry, revolves round internal fixation devices, particularly the design of plates (Martineau 2007). It is important to assess the clinical evidence, particularly in terms of function and adverse effects, for the use internal fixation and related techniques and devices. Additionally it is important to compare internal fixation with other commonly used methods of surgical fixation (percutaneous pinning, external fixation); and, to complete the picture, to review comparisons of all these methods, including the use of bone grafts and bone substitutes. In their meta-analysis drawing data from 46 articles, predominantly case series, comparing plate osteosynthesis with bridging external fixation, Margaliot 2005 concluded the current literature "offers no evidence to support the use of internal fixation over external fixation". However, the approach taken by Margaliot 2005 including their study inclusion criteria is substantially different from our methods and we will also include more recent evidence. Other important questions also need assessment. These include the repair of ruptured ligaments and use of adjunctive arthroscopy. The findings of the review are likely to depend on fracture configuration, bone quality and other patient factors.

\section{O B J E C T I V E S}

To evaluate the effectiveness of internal fixation for fractures of the distal radius in skeletally mature people. Additionally, to evaluate the relative effectiveness of different surgical methods of treating these fractures.

More specifically, we will compare the effectiveness of:

- internal fixation versus conservative treatment;

- different methods of internal fixation, including different techniques associated with inserting implants, different implants, and different types and durations of immobilisation after internal fixation;

- different fixation methods (percutaneous pinning, external fixation, internal fixation); and different combinations of surgical methods;

- different techniques (e.g. use of arthroscopy) and approaches (e.g. surgical repair of the triangular fibrocartilagenous complex (fibrous tissue which binds together the distal ends of the radius and ulnar)) not already covered. 
We will consider these outcomes primarily in terms of patientassessed functional outcome and satisfaction, and other measures of function and impairment, pain and discomfort, the incidence of complications, anatomical deformity and use of resources.

If data allow it, we intend to study the outcomes in different age groups and for different types of fractures, especially whether they are extra-articular or intra-articular.

\section{METHODS}

\section{Criteria for considering studies for this review}

\section{Types of studies}

Any randomised or quasi-randomised (method of allocating participants to a treatment which is not strictly random e.g. by date of birth, hospital record number, alternation) controlled clinical trials evaluating internal fixation or comparing different methods of surgical fixation for treating distal radial fractures in adults.

\section{Types of participants}

Skeletally mature patients of either sex with a fracture of the distal radius. Trials containing adults and children will be included provided the proportion of children was clearly small $(<5 \%)$, or separate data for adults can be obtained. Trials containing different fracture types will only be included if separate data are available for participants with distal radial fractures. Also included will be trials recruiting people whose fractures have redisplaced within two weeks of conservative management.

\section{Types of interventions}

This includes three groups of comparisons.

\section{(A) Internal fixation}

(1) Internal fixation by itself versus conservative interventions such as plaster cast immobilisation.

(2) Internal fixation as the primary method where a combination of methods is used (e.g. with supplementary percutaneous pinning, bone grafts or bone substitutes) versus conservative interventions such as plaster cast immobilisation.

(3) Different methods of internal fixation. Thus comparisons evaluating:

(a) different fixation methods (e.g. fragment-specific fixation versus fixed-angle plates; locked versus non-locking plates);

(b) different types of devices, including materials used (e.g. bioabsorbable versus metal implants);

(c) different approaches (e.g. dorsal versus volar fixation);

(d) different surgical techniques associated with internal fixation, including location and extent of skin incision and measures to assist reduction, and methods of implant removal (where indicated); (e) type and duration of immobilisation after internal fixation;

(f) policy and timing of implant removal.

(B) Comparisons of different fixation methods (percutaneous pinning, external fixation, internal fixation)

(1) External fixation versus percutaneous pinning.

(2) Internal fixation versus percutaneous pinning.

(3) Internal fixation versus external fixation.

Within each comparison, we will consider prespecified subcategories of the methods of fixation being compared. For percutaneous pinning, these will be transfixation of the fracture fragments versus Kapandji pinning; for external fixation, these will be bridging versus non-bridging of the radiocarpal joint; for internal fixation, these will be dorsal versus volar plating; and fragment specific versus fixed-angle plating. Other subcategories will include the use of i) bone graft or substitutes and ii) supplementary pinning where these apply to either both intervention groups or to only one intervention group.

\section{(C) 'Miscellaneous'}

Randomised trials testing other comparisons of surgical fixation for these fractures that do not fall within the above categories or within the scope of the four other reviews (Handoll 2007a; Handoll 2007b; Handoll 2007c; Handoll 2007d) will be considered for inclusion on a case by case basis. Two prespecified categories follow.

(1) Surgical repair of the triangular fibrocartilagenous complex rupture or ulnar styloid fractures, or both versus no repair. Patients in both groups may otherwise receive either conservative treatment or the same type of surgical treatment.

(2) Arthroscopic versus other methods of visualisation and reduction.

\section{Types of outcome measures}

Our primary outcome of choice would be the number of people with an uncomplicated and swift restoration of a pain-free fullyfunctioning wrist and arm with acceptable anatomic restoration and appearance. However, compatible with the general assessment and presentation of outcome within the orthopaedic literature, we shall report outcome in the following four categories.

\section{Primary outcomes}

(1) Functional outcome and impairment

- Patient functional assessment instruments such as Short Form-36 (SF-36), the Disability of the Arm, Shoulder, and Hand questionnaire (DASH) and the Patient-Rated Wrist Evaluation (PRWE) (MacDermid 2000)

- Return to previous occupation, including work, and activities of daily living

- Grip strength

- Pain

- Range of movement (wrist and forearm mobility): range of movement for the wrist is described in terms of six parameters: flexion (ability to bend the wrist downwards) and extension (or 
upwards); radial deviation (ability to bend the wrist sideways on the thumb side) and ulnar deviation (on the little finger side); and pronation (ability to turn the forearm so that the palm faces downwards) and supination (palm faces upwards)

\section{(2) Clinical outcome}

- Residual soft tissue swelling

- Early and late complications associated with distal radial fractures or their treatment, including complex regional pain syndrome type 1 (CRPS-1), late tendon rupture and post traumatic osteoarthritis

- Cosmetic appearance

- Patient satisfaction with treatment

\section{Secondary outcomes}

(3) Anatomical outcome (anatomical restoration and residual deformity)

- Radiological parameters include radial length or shortening and shift, dorsal angulation, radial inclination or angle, ulnar variance, and for intra-articular fractures: step off and gap deformity of the articular surface (Fernandez 1996; Kreder 1996). Composite measures include malunion and total radiological deformity. Definitions of four of the most commonly reported radiological parameters are presented in Table 2.

Table 2. Definitions of key radiological parameters

\begin{tabular}{|c|c|c|}
\hline Parameter & Definition & Normal value \\
\hline $\begin{array}{l}\text { Dorsal angulation (dorsal or volar or pal- } \\
\text { mar tilt) }\end{array}$ & $\begin{array}{l}\text { Angle between a) the line which connects } \\
\text { the most distal points of the dorsal and } \\
\text { volar cortical rims of the radius and b) the } \\
\text { line drawn perpendicular to the longitudi- } \\
\text { nal axis of the radius. Side view of wrist. }\end{array}$ & $\begin{array}{l}\text { Palmar or volar tilt: approximately 11-12 } \\
\text { degrees. }\end{array}$ \\
\hline Radial length & $\begin{array}{l}\text { Distance between a) a line drawn at the tip } \\
\text { of the radial styloid process, perpendicular } \\
\text { to the longitudinal axis of the radius and } \\
\text { b) a second perpendicular line at the level } \\
\text { of the distal articular surface of the ulnar } \\
\text { head. Frontal view. }\end{array}$ & Approximately 11-12 mm. \\
\hline Radial angle or radial inclination & $\begin{array}{l}\text { Angle between a) the line drawn from the } \\
\text { tip of the radial styloid process to the ulnar } \\
\text { corner of the articular surface of the distal } \\
\text { end of the radius and b) the line drawn } \\
\text { perpendicular to the longitudinal axis of } \\
\text { the radius. Frontal view. }\end{array}$ & Approximately $22-23$ degrees. \\
\hline Ulnar variance & $\begin{array}{l}\text { Vertical distance between a) a line drawn } \\
\text { parallel to the proximal surface of the lu- } \\
\text { nate facet of the distal radius and b) a line }\end{array}$ & $\begin{array}{l}\text { Usually negative variance (e.g. }-1 \mathrm{~mm} \text { ) or } \\
\text { neutral variance. }\end{array}$ \\
\hline
\end{tabular}


Table 2. Definitions of key radiological parameters (Continued)

parallel to the articular surface of the ulnar

head.

\section{(4) Resource use}

- Hospital stay, number of outpatient attendances, physiotherapy and other costs.

\section{Intervention-specific outcomes}

Complications associated with hardware failure and subsequent extraction of internal fixation devices will be collected, and presented in the analyses. For autografts, outcomes including pain and complications associated with the surgical removal of bone from the donor site will be collected, where reported, and presented in the analyses.

\section{Search methods for identification of studies}

\section{Electronic searches}

We will search the Cochrane Bone, Joint and Muscle Trauma Group Specialised Register, the Cochrane Central Register of Controlled Trials (in The Cochrane Library) (see Appendix 1), MEDLINE, EMBASE, CINAHL and reference lists of articles. We will also search Current Controlled Trials at www.controlled-trials.com and the UK National Research Register at www.updatesoftware.com/national/ for ongoing and recently completed trials. No language restrictions will be applied.

In MEDLINE (OVID-WEB) the search strategy will be combined with all three sections of the optimal MEDLINE search strategy for randomised trials (Higgins 2005) (see Appendix 2). Similar search strategies will be used for EMBASE (OVID-WEB) and CINAHL (OVID-WEB) (see Appendix 3).

\section{Searching other resources}

We will include the findings from handsearches of the British Volume of the Journal of Bone and Joint Surgery supplements (1996 onwards) and abstracts of the American Society for Surgery of the Hand annual meetings (2000 onwards: www.assh.org/ ), the American Orthopaedic Trauma Association annual meetings (1996 onwards: www.ota.org/education/archives.html) and
American Academy of Orthopaedic Surgeons annual meeting (2004 onwards: www.aaos.org/). We will also include handsearch results from the final programmes of SICOT (1996 \& 1999) and SICOT/SIROT (2003), and the British Orthopaedic Association Congress (2000, 2001, 2002 and 2003), and various issues of Orthopaedic Transactions and of Acta Orthopaedica Scandinavica Supplementum.

We will also scrutinise weekly downloads of "Fracture" articles in new issues of 15 journals (Acta Orthop Scand; Am J Orthop; Arch Orthop Trauma Surg; Clin J Sport Med; Clin Orthop; Foot Ankle Int; Injury; J Am Acad Orthop Surg; J Arthroplasty; J Bone Joint Surg Am; J Bone Joint Surg Br; J Foot Ankle Surg; J Orthop Trauma; J Trauma; Orthopedics) from AMEDEO (www.amedeo.com).

\section{Data collection and analysis}

\section{Selection of studies}

Both review authors will independently assess potentially eligible trials identified via the search for inclusion using a pre-piloted form. Any disagreement will be resolved by discussion.

\section{Data extraction and management}

Using a data extraction form, both review authors will independently extract trial details and data for new trials, and one author $(\mathrm{HH})$ will repeat data extraction of trials already included in Handoll 2003a and check for consistency with her previous data extraction. HH will enter the data into RevMan. Any disagreement for new trials will be resolved by discussion. Extraction of results from graphs in trial reports will be considered where data are not provided in the text or tables. We will contact trialists of trials not reported in full journal publications for additional information or data. Contact with other trial authors will be dictated by the vintage of the publication, a general impression of the expected gain, and anticipated or known difficulty in locating trial authors.

Results will be collected for the final follow-up time for which these are available. We will, however, note instances where a marked and important difference between groups in the pattern of functional recovery has been found at an intermediate assessment.

Assessment of methodological quality of included studies In this review, risk of bias will be assessed indirectly in terms of different aspects of methodological quality. 
Both review authors will independently assess methodological quality of the newly included trials using a pre-piloted form. One author $(\mathrm{HH})$ will reassess the trials already included in Handoll 2003a. Any disagreement will be resolved by discussion. Titles of journals, names of authors or supporting institutions will not be masked at any stage. A modification of the quality assessment tool used in the current 'umbrella' review will be used. Instead of scores, each item will be graded either ' $\mathrm{Y}$ ', '?' or 'N', respectively indicating that the quality criteria were met for the item ("Yes"), or possibly or only partially met for the item ("Possible, partial"), or not met ("No"). The rating scheme covering 11 aspects of trial validity plus brief notes of coding guidelines for selected items are given in Table 3.

Table 3. Methodological quality assessment scheme

\begin{tabular}{lll}
\hline Items & Scores & Notes \\
\hline $\begin{array}{ll}\text { (1) Was the assigned treatment adequately } \\
\text { concealed prior to allocation? }\end{array}$ & $\begin{array}{l}\text { Y = method did not allow disclosure of as- } \\
\text { signment. } \\
\text { ? = small but possible chance of disclosure } \\
\text { of assignment or unclear. } \\
\text { N = quasi-randomised, or open list or ta- } \\
\text { bles. }\end{array}$ & $\begin{array}{l}\text { yes = A; Not sure = B; Clearly no = C. } \\
\end{array}$ \\
\hline
\end{tabular}

(2) Were the outcomes of participants who $Y=$ withdrawals well described and acwithdrew described and included in the counted for in analysis. analysis (intention-to-treat)?

? = withdrawals described and analysis not possible, or probably no withdrawals.

$\mathrm{N}=$ no mention, inadequate mention, or obvious differences and no adjustment.

(3) Were the outcome assessors blinded to $Y=$ effective action taken to blind assessors. treatment status?

$?=$ small or moderate chance of unblinding of assessors, or some blinding of outcomes attempted.

$\mathrm{N}=$ not mentioned or not possible.

(4) Were important baseline characteristics reported and comparable?
$\mathrm{Y}=$ good comparability of groups, or confounding adjusted for in analysis.

$?=$ confounding small, mentioned but not adjusted for, or comparability reported in text without confirmatory data.

$\mathrm{N}=$ large potential for confounding, or not discussed.
(5) Were the trial participants blind to assignment status after allocation?
Although many characteristics including hand dominance are important, the principal confounders are considered to be age, gender, type of fracture.

$\mathrm{Y}=$ effective action taken to blind participants.

$?=$ small or moderate chance of unblinding of participants. 
Table 3. Methodological quality assessment scheme (Continued)

$\mathrm{N}=$ not possible, or not mentioned (unless double-blind), or possible but not done.

(6) Were the treatment providers blind to $\mathrm{Y}=$ effective action taken to blind treatment assignment status? providers.

? = small or moderate chance of unblinding of treatment providers.

$\mathrm{N}=$ not possible, or not mentioned (unless double-blind), or possible but not done.

(7) Were care programmes, other than the $Y=$ care programmes clearly identical. trial options, identical?
? = clear but trivial differences, or some evidence of comparability.

$\mathrm{N}=$ not mentioned or clear and important differences in care programmes.
Examples of clinically important differences in other interventions are: time of intervention, duration of intervention, anaesthetic used within broad categories, operator experience, difference in rehabilitation.

(8) Were the inclusion and exclusion criteria for entry clearly defined?

$\mathrm{Y}=$ clearly defined (including type of fracture).

$?=$ inadequately defined.

$\mathrm{N}=$ not defined.

(9) Were the outcome measures used clearly $\mathrm{Y}=$ clearly defined.

defined?

$?=$ inadequately defined.

$\mathrm{N}=$ not defined.

(10) Were the accuracy and precision, $Y=$ optimal.

with consideration of observer variation, of $?=$ adequate.

the outcome measures adequate; and were $\mathrm{N}=$ not defined, not adequate.

these clinically useful and did they include active follow up?

(11) Was the timing (e.g. duration of $\mathrm{Y}=$ optimal. ( $>1$ year)

surveillance)clinically appropriate? ? = adequate. (6 months -1 year)

$\mathrm{N}=$ not defined, not adequate. $(<6$

months)

\section{Measures of treatment effect}

Quantitative data reported in individual trial reports for outcomes listed in the inclusion criteria will be presented in the text and in the analyses, using relative risks with $95 \%$ confidence intervals for dichotomous outcomes, and mean differences with $95 \%$ confidence intervals for continuous outcomes.

\section{Unit of analysis issues}

The unit of randomisation in these trials is usually the individual patient. Exceptionally, as in the case of trials including people with bilateral fractures, data for trials may be presented for fractures or limbs rather than individual patients. Where such unit of analysis issues arise and appropriate corrections have not been made, we will consider presenting the data for such trials only where the disparity between the units of analysis and randomisation is small. Where data are pooled, we will perform a sensitivity analysis to examine the effects of pooling these incorrectly analysed trials with the other correctly analysed trials. 


\section{Dealing with missing data}

Where appropriate, we will perform intention-to-treat analyses to include all people randomised to the intervention groups. We will investigate the effect of drop outs and exclusions by conducting worse and best scenario analyses. We will be alert to the potential mislabelling or non identification of standard errors and standard deviations. Unless missing standard deviations can be derived from confidence interval data, we will not assume values in order to present these in the analyses.

\section{Assessment of heterogeneity}

Heterogeneity will be assessed by visual inspection of the forest plot (analysis) along with consideration of the test for heterogeneity and the $\mathrm{I}^{2}$ statistic (Higgins 2003).

\section{Assessment of reporting biases}

In the unlikely event that sufficient data are available, we would attempt to assess publication bias by preparing a funnel plot. Our search of 'grey literature' and pursuit of trials listed in clinical trial registers should help to avoid publication bias.

\section{Data synthesis (meta-analysis)}

If considered appropriate, results of comparable groups of trials will be pooled. Initially we will use the fixed-effect model and $95 \%$ confidence intervals. We will also consider using the randomeffects model, especially where there is unexplained heterogeneity.

\section{Subgroup analysis and investigation of heterogeneity}

We plan subgroup analyses by age (under 50; 50 or above) and gender and type of fracture (primarily extra-articular versus intraarticular fractures). Presentation in separate subgroups will be considered where there is a fundamental difference in bone scaffolding (such as bone graft versus bone substitute). To test whether the subgroups are statistically significantly different from one another, we will test the interaction using the technique outlined in Altman 2003.

\section{Sensitivity analysis}

Where possible, we plan sensitivity analyses examining various aspects of trial and review methodology, including the effects of missing data, study quality (specifically allocation concealment, outcome assessor blinding and reportage of surgical experience), and inclusion of trials only reported in abstracts. We will use the test of interaction to establish whether the subgroups are statistically significantly different from one another (Altman 2003).

\section{Interpretation of the evidence}

To assist our interpretation of the evidence, we will grade the findings of the treatment comparisons according to the six categories of effectiveness used by contributors to Clinical Evidence (BMJ 2006) (see Table 4).

Table 4. Categories of effectiveness (definitions)

\begin{tabular}{|c|c|c|}
\hline Rank & Category & Definition \\
\hline 1 & Beneficial & $\begin{array}{l}\text { Interventions for which effectiveness has been demonstrated by clear evidence from } \\
\text { randomised controlled trials, and for which expectation of harms is small compared } \\
\text { with the benefits. }\end{array}$ \\
\hline 2 & Likely to be beneficial & $\begin{array}{l}\text { Interventions for which effectiveness is less well established than for those listed } \\
\text { under "beneficial". }\end{array}$ \\
\hline 3 & Trade off between benefits and harms & $\begin{array}{l}\text { Interventions for which clinicians and patients should weigh up the beneficial and } \\
\text { harmful effects according to individual circumstances and priorities. }\end{array}$ \\
\hline 4 & Unknown effectiveness & $\begin{array}{l}\text { Interventions for which there is currently insufficient data or data of inadequate } \\
\text { quality. }\end{array}$ \\
\hline 5 & Unlikely to be beneficial & $\begin{array}{l}\text { Interventions for which lack of effectiveness is less well established than for those } \\
\text { listed under "likely to be ineffective or harmful" }\end{array}$ \\
\hline 6 & Likely to be ineffective or harmful & $\begin{array}{l}\text { Interventions for which ineffectiveness or harmfulness has been demonstrated by } \\
\text { clear evidence. }\end{array}$ \\
\hline
\end{tabular}




\section{ACKNOWLEDGEMENTS}

We thank Lesley Gillespie for her help with the search strategy. We thank the following for helpful comments and input at the editorial and external review of the protocol: Bill Gillespie, Jesse Jupiter and Janet Wale. We thank Joanne Elliott and Lindsey Elstub for their help during editorial processing.

\section{REFERE N CES}

\section{Additional references}

\section{Altman 2003}

Altman DG, Bland JM. Interaction revisited: the difference between two estimates. BMJ 2003;326(7382):219.

Arora 2007

Arora R, Lutz M, Hennerbichler A, Krappinger D, Espen D, Gabl M. Complications following internal fixation of unstable distal radius fracture with a palmar locking-plate. Journal of Orthopaedic Trauma 2007;21(5):316-22.

Atkins 2003

Atkins RM. Aspects of current management: Complex regional pain syndrome. Journal of Bone \& Joint Surgery - British Volume 2003;85(8):1100-6.

\section{Belsole 1993}

Belsole RJ, Hess AV. Concomitant skeletal and soft tissue injuries. Orthopedic Clinics of North America 1993;24(2):327-31.

\section{BMJ 2006}

A guide to the text. Clinical Evidence Online http://

www.clinicalevidence.com/ceweb/about/guide.jsp (accessed 24 March 2006).

\section{Chitnavis 1999}

Chitnavis J. The wrist. In: Pynsent PB, Fairbank JC, Carr AJ editor (s). Classification of musculoskeletal trauma. Oxford: Butterworth Heinemann, 1999:146-70.

\section{Cooney 1993}

Cooney WP. Fractures of the distal radius. A modern treatmentbased classification. Orthopedic Clinics of North America 1993;24 (2):211-6.

\section{Cummings 1985}

Cummings SR, Kelsey JL, Nevitt MC, O’Dowd KJ. Epidemiology of osteoporosis and osteoporotic fractures. Epidemiologic Reviews 1985;7:178-208.

\section{Fernandez 1993}

Fernandez DL. Fractures of the distal radius: operative treatment. Instructional Course Lectures 1993;42:73-88.

\section{Fernandez 1996}

Fernandez DL, Jupiter JB. Fractures of the distal radius. A practical approach to management. 1st Edition. New York: Springer-Verlag, 1996.
Frykman 1967

Frykman G. Fracture of the distal radius including sequelae-shoulder-hand-finger syndrome, disturbance in the distal radioulnar joint and impairment of nerve function. A clinical and experimental study. Acta Orthopaedica Scandinavica Supplementum 1967;108:3-153.

\section{Gartland 1951}

Gartland JJ, Werley CW. Evaluation of healed Colles' fractures. Journal of Bone and Joint Surgery - American Volume 1951;33(4): 895-910.

\section{Handoll 2003a}

Handoll HHG, Madhok R. Surgical interventions for treating distal radial fractures in adults. Cochrane Database of Systematic Reviews 2003, Issue 3. [DOI: 10.1002/14651858.CD003209]

\section{Handoll 2003b}

Handoll HHG, Madhok R. Conservative interventions for treating distal radial fractures in adults. Cochrane Database of Systematic Reviews 2003, Issue 2. [DOI: 10.1002/14651858.CD000314]

\section{Handoll 2003c}

Handoll HHG, Madhok R. Closed reduction methods for treating distal radial fractures in adults. Cochrane Database of Systematic Reviews 2003, Issue 1. [DOI: 10.1002/14651858.CD003763]

Handoll 2007a

Handoll HHG, Vaghela M, Madhok R. Percutaneous pinning for treating distal radial fractures in adults. Cochrane Database of Systematic Reviews 2007, Issue 3. [DOI: 10.1002/ 14651858.CD006080.pub2]

Handoll 2007b

Handoll HHG, Hunter JS, Madhok R. External fixation versus conservative treatment for distal radial fractures in adults. Cochrane Database of Systematic Reviews 2007, Issue 3. [DOI: 10.1002/ 14651858.CD006194.pub2]

Handoll 2007c

Handoll HHG, Madhok R, Hunter JS. Different methods of external fixation for treating distal radial fractures in adults. Cochrane Database of Systematic Reviews 2007, Issue 2. [DOI: 10.1002/14651858.CD006522]

\section{Handoll 2007d}

Handoll HHG, Watts AC. Bone grafts and bone substitutes for treating distal radial fractures in adults. Cochrane Database of 
Systematic Reviews 2007, Issue 4. [DOI: 10.1002/ 14651858.CD006836]

\section{Higgins 2003}

Higgins JP, Thompson SG, Deeks JJ, Altman DG. Measuring inconsistency in meta-analyses. BMJ 2003;327(7414):557-60.

\section{Higgins 2005}

Higgins JPT, Green S, editors. Highly sensitive search strategies for identifying reports of randomized controlled trials in MEDLINE. Cochrane Handbook for Systematic Reviews of Interventions 4.2.5 [updated May 2005]; Appendix 5b. www.cochrane.org/resources/ handbook/hbook.htm (accessed 31 July 2007).

\section{Knirk 1986}

Knirk JL, Jupiter JB. Intra-articular fractures of the distal end of the radius in young adults. Journal of Bone and Joint Surgery - American Volume 1986;68(5):647-59.

\section{Kreder 1996}

Kreder HJ, Hanel DP, McKee M, Jupiter J, McGillivary G, Swiontkowski MF. X-ray film measurements for healed distal radius fractures [published erratum appears in J Hand Surg [Am] 1996 May;21(3):532]. Journal of Hand Surgery - American Volume 1996; 21(1):31-9.

\section{MacDermid 2000}

MacDermid JC, Richards RS, Donner A, Bellamy N, Roth JH. Responsiveness of the short form-36, disability of the arm, shoulder, and hand questionnaire, patient-rated wrist evaluation, and physical impairment measurements in evaluating recovery after a distal radius fracture. Journal of Hand Surgery - American Volume 2000;25(2):330-40.

\section{Margaliot 2005}

Margaliot Z, Haase SC, Kotsis SV, Kim HM, Chung KC. A metaanalysis of outcomes of external fixation versus plate osteosynthesis for unstable distal radius fractures. Journal of Hand Surgery American Volume 2005;30(6):1185-99.

\section{Martineau 2007}

Martineau PA, Berry GK, Harvey EJ. Plating for distal radius fractures. Orthopedic Clinics of North America 2007;38(2):193-201.

\section{McKay 2001}

McKay SD, MacDermid JC, Roth JH, Richards RS. Assessment of complications of distal radius fractures and development of a complication checklist. Journal of Hand Surgery - American Volume 2001;26(5):916-22.

\section{McQueen 2003}

McQueen MM, Court-Brown CM. Increasing age and fractures of the distal radius. Current Orthopaedics 2003;17(5):360-8.
Melone 1993

Melone CPJr. Distal radius fractures: patterns of articular fragmentation. Orthopedic Clinics of North America 1993;24(2): 239-53.

Muller 1991

Muller M, Allgower M, Schneider R, Willenegger H. Manual of internal fixation: techniques recommended by the AO-ASIF Group. 3rd Edition. Berlin: Springer-Verlag, 1991.

\section{O’Neill 2001}

O’Neill TW, Cooper C, Finn JD, Lunt M, Purdie D, Reid DM, et al.Incidence of distal forearm fracture in British men and women. Osteoporosis International 2001;12(7):555-8.

\section{Older 1965}

Older TM, Stabler EV, Cassebaum WH. Colles fracture: Evaluation and selection of therapy. Journal of Trauma-Injury Infection \& Critical Care 1965;5(4):469-76.

\section{Sahlin 1990}

Sahlin Y. Occurrence of fractures in a defined population: a 1-year study. Injury 1990;21(3):158-60.

Simic 2003

Simic PM, Weiland AJ. Fractures of the distal aspect of the radius: Changes in treatment over the past two decades. Journal of Bone \& Joint Surgery - American Volume 2003;85(3):552-64.

\section{Singer 1998}

Singer BR, McLauchlan GJ, Robinson CM, Christie J. Epidemiology of fractures in 15,000 adults: the influence of age and gender. Journal of Bone and Joint Surgery - British Volume 1998; 80(2):243-8.

\section{Taleisnik 1984}

Taleisnik J, Watson HK. Midcarpal instability caused by malunited fractures of the distal radius. Journal of Hand Surgery - American Volume 1984;9(3):350-7.

Trumble 1998

Trumble TE, Wagner W, Hanel DP, Vedder NB, Gilbert M. Intrafocal (Kapandji) pinning of distal radius fractures with and without external fixation. Journal of Hand Surgery - American Volume 1998;23(3):381-94.

\section{Van Staa 2001}

Van Staa TP, Dennison EM, Leufkens HG, Cooper C. Epidemiology of fractures in England and Wales. Bone 2001;29(6): 517-22.

* Indicates the major publication for the study 


\section{A P P E N D I CES}

\section{Appendix I. Search strategy for The Cochrane Library (Wiley InterScience)}

\#1 MeSH descriptor Radius Fractures explode all trees in MeSH products \#2 MeSH descriptor Wrist Injuries explode all trees in MeSH products \#3 (\#1 OR \#2)

\#4 ((distal near radius) or (distal near radial)) in Title, Abstract or Keywords in all products \#5 (colles or smith or smiths) in Title, Abstract or Keywords in all products \#6 wrist* in Title, Abstract or Keywords in all products \#7 (\#4 OR \#5 OR \#6)

$\# 8$ fractur* in Title, Abstract or Keywords in all products \#9 (\#7 AND \#8)

\#10 (\#3 OR \#9)

\section{Appendix 2. Search strategy for MEDLINE (OVID-WEB)}

1. exp Radius Fractures/

2. Wrist Injuries/

3. (((distal adj3 (radius or radial)) or wrist or colles or smith\$2) adj3 fracture\$).ti,ab.

4. or/1-3

Appendix 3. Search strategies for CINAHL and EMBASE (OVID-WEB)

\section{CINAHL}

1. Radius Fractures/

2. Wrist Injuries/

3. or/ $1-2$

4. (((distal adj3 (radius or radial)) or wrist or colles or smith $\$ 2$ ) adj3 fracture\$).ti,ab.

5. or $/ 3-4$

6. $\exp$ Clinical Trials/

7. exp Evaluation Research/

8. exp Comparative Studies/

9. exp Crossover Design/

10. clinical trial.pt.

11. or/6-10

12. ((clinical or controlled or comparative or placebo or prospective or randomi\#ed)adj3 (trial or study)).tw.

13. (random $\$$ adj7 (allocat $\$$ or allot $\$$ or assign $\$$ or basis $\$$ or divid $\$$ or order $\$))$.tw.

14. ((singl\$ or doubl\$ or trebl\$ or tripl\$) adj7 (blind\$ or mask\$) ) .tw.

15. (cross?over\$ or (cross adj1 over\$)).tw.

16. ((allocat $\$$ or allot $\$$ or assign $\$$ or divid $\$$ ) adj3 (condition $\$$ or experiment $\$$ or intervention $\$$ or treatment $\$$ or therap $\$$ or control\$ or group\$)).tw.

17. or/12-16

18. or/ 11,17

\section{EMBASE}

1. (((distal adj3 (radius or radial)) or wrist or colles $\$ 2$ or smith $\$ 2)$ adj3 fracture $\$) . t w$.

2. Colles Fracture/ or Radius Fracture/ or Wrist Fracture/ or Wrist Injury/

3. or/1-2

4. exp Randomized Controlled trial/

5. exp Double Blind Procedure/

6. exp Single Blind Procedure/

7. $\exp$ Crossover Procedure/

8. or/4-8

9. ((clinical or controlled or comparative or placebo or prospective $\$$ or randomi\#ed)adj3 (trial or study)).tw.

10. (random \$ adj7 (allocat $\$$ or allot $\$$ or assign $\$$ or basis $\$$ or divid $\$$ or order\$)).tw.

11. ((singl\$ or doubl\$ or trebl\$ or tripl\$) adj7 (blind\$ or mask\$) ) .tw.

12. (cross?over\$ or (cross adj1 over\$)).tw.

13. ((allocat\$ or allot\$ or assign\$ or divid\$) adj3 (condition\$ or experiment $\$$ or intervention $\$$ or treatment $\$$ or therap $\$$ or control\$ or group\$)).tw.

14. or/9-13

15. or $/ 8,14$

16. Animal/ not Human/

17. 15 not 16 
WHAT'S NEW

25 July 2008 Amended Converted to new review format.

\section{H I S T O R Y}

Protocol first published: Issue 1, 2008

\section{DECLARATIONS OF INTEREST}

None known

\section{SOURCES OF SUPPORT}

\section{Internal sources}

- University of Teesside, Middlesbrough, UK.

\section{External sources}

- No sources of support supplied 